\title{
Elective amputation of the upper limb is an option in the treatment of traumatic injuries of the brachial plexus?
}

\author{
A amputação eletiva do membro superior é uma opção no tratamento das lesões \\ traumáticas do plexo braquial?
}

Mário Gilberto Siqueira ${ }^{1}$, Roberto Sérgio Martins', Carlos Otto Heise ${ }^{1}$, Luciano Foroni ${ }^{1}$

\begin{abstract}
The treatment of complete post-traumatic brachial plexus palsy resulting in a flail shoulder and upper extremity remains a challenge to peripheral nerve surgeons. The option of upper limb amputation is controversial and scarcely discussed in the literature. We believe that elective amputation still has a role in the treatment of select cases. The pros and cons of the procedure should be intensely discussed with the patient by a multidisciplinary team. Better outcomes are usually achieved in active patients who strongly advocate for the procedure.
\end{abstract}

Keywords: brachial plexus neuropathies; amputation; upper extremity; artificial limbs

\section{RESUMO}

O tratamento das paralisias completas após lesões traumáticas do plexo braquial que resultam em um membro superior completamente paralisado permanecem como um desafio aos cirurgiões de nervos periféricos. A opção de amputar o membro superior é controversa e raramente discutida na literatura. Acreditamos que a amputação eletiva ainda tem utilidade no tratamento de casos selecionados. Os prós e contras do procedimento devem ser intensamente discutidos com o paciente por uma equipe multidisciplinar. Os melhores resultados são geralmente obtidos em pacientes atuantes que reivindicam vigorosamente o procedimento.

Palavras-chave: neuropatias do plexo braquial; amputação; extremidade superior; dor por deaferentação; membros artificiais

In traction injuries of the brachial plexus the end result of a complete injury is a flail upper extremity. Severe pain is usually associated with this, and most of its source is related to the damage of the dorsal root entry zone of the spinal cord. Following World War II, the standard approach to these lesions was surgical reconstruction by shoulder fusion, elbow bone block, and finger tenodesis ${ }^{1}$. In the 1960s and until the early 1970s, transhumeral amputation, combined with shoulder fusion in slight abduction and flexion, and fitting of a limb prosthesis, was advocated based on the concept that a paralyzed and insensate limb is a hindrance to function and that the results from surgical treatment were far from acceptable $e^{2,3}$. At that time, amputation-arthrodesis offered better functional results than either reconstruction or no operation. With the introduction of microsurgical techniques and improvement of surgical results, indications for elective amputation became much less common. However, although not frequent, elective amputation should be offered to patients in certain conditions.

\section{LITERATURE ANALYSIS}

Analyzing the literature, it is easy to conclude that the place for amputation in the treatment of complete lesions of the brachial plexus is still controversial. Yeoman and Seddon ${ }^{4}$ reported on 17 cases of amputations in patients with complete paralysis, emphasizing that the shorter the gap between accident and surgery, the better the result. They also found that patients whose jobs required manual dexterity were more likely to use their prosthesis and to return to their previous employments. Wynn Parry ${ }^{3}$ reported on 14 patients who had above-elbow amputation and shoulder arthrodesis within six months of injury, with ten returning to work within one year; but further follow up revealed that most of them were working without their prosthesis. These results led the authors to a more conservative attitude toward early amputation. In Ransford and Hughes ${ }^{5}$ series of 13 patients who had amputations, only a few continued to use their prosthesis.

'Universidade de São Paulo, Instituto de Psiquiatria, Divisão de Neurocirurgia Funcional, Grupo de Cirurgia do Nervo Periférico, São Paulo SP, Brasil. Correspondence: Mario Giberto Siqueira; Rua Rua Virgilio de Carvalho Pinto, 381 / apto. 42; 05415-030 São Paulo SP, Brasil; E-mail:mgsiqueira@uol.com.br Conflict of interest: There is no conflict of interest to declare.

Received 19 May 2017; Accepted 02 June 2017. 
Rorabeck ${ }^{6}$ reported findings similar to Yeoman and Seddon ${ }^{4}$ in a study of 23 patients with complete brachial plexus lesions. Amputation within one year of injury was correlated with an earlier return to work and with more frequent use of the prosthesis. In 1987, Wynn Parry et al. ${ }^{7}$ published a new series with 24 patients who underwent amputation and were provided with a prosthesis. Eighteen patients never used the artificial limb, and of the six who did, three used it only for cosmetic reasons. At that time, this author concluded that there was no longer any place for amputation except in very special circumstances when the patient demanded it. Wilkinson et al. ${ }^{8}$ amputated the limb of 13 patients who requested this type of treatment and all of them felt that their lives had been improved by the operation. Bedi et al. ${ }^{9}$, combining glenohumeral arthrodesis and above-elbow amputation, improved shoulder stability and rehabilitation with the use of a prosthesis. Birch ${ }^{10}$ reported on 73 patients submitted to aboveelbow amputations. All, save one, of these patients felt a great deal better. Maldonado et al. ${ }^{11}$ evaluated elective amputation in nine patients. All of them were satisfied with the procedure, but none used a functional prosthesis. A cosmetic prosthesis was used by three patients. It is interesting to note that some prominent authors, from the beginning of the microsurgical era of treatment of traumatic brachial plexus injuries seldom, if ever, chose amputation as a form of treatment. Narakas ${ }^{12}$ performed only three amputations in a series of 508 patients with traction injuries. Sedel ${ }^{13}$ reported no amputations among the 139 patients in his series. Allieu and $\mathrm{Cenac}^{14}$ reported only one case of amputation, requested by the patient, in his series of 28 patients with complete brachial plexus palsies. His patients were more concerned with appearance than functional ability and refused amputation.

\section{DISCUSSION}

Patients experiencing traumatic brachial plexus injuries still present with high levels of disability owing to limitations of the current surgical repair strategies. On the other hand, the evolution of prosthetic design has provided increasing restoration of function ${ }^{15}$, allowing some patients to return to some of their previous activities, with obvious psychosocial and physical benefits ${ }^{16}$. However, regardless of advances in prosthetic technology, elective amputation and prosthetic replacement of functionally impaired limbs is not a common practice ${ }^{16}$.

When confronted with a patient with a definitive diagnosis of complete irreparable brachial plexus injury, in whom every reasonable attempt to repair the nervous lesion has been made, the attending surgeon is faced with three options ${ }^{6}$ : first, ignore the compromised extremity and focus the rehabilitation on improving function in the normal arm; second, perform an above-elbow amputation alone, and third, perform an above-elbow amputation combined with arthrodesis of the shoulder. The second and third options could be combined, or not, with a prosthesis. Before the amputation procedure, the patient must have long discussions with the surgeons, rehabilitation staff, psychologists, the prosthesis team and, if possible, have contact with previous amputee patients $^{11}$. Once all the positive and negative aspects of the procedure are presented and the patient still requests it, the indication for a selective amputation consolidates and the possibility of a reasonable outcome increases.

The level of amputation is usually through the middle of the upper arm, just distal to the deltoid insertion (Figure A and B). Arthrodesis generally is not done at the first operation, and should be reserved for those patients wholly committed to the idea of using a prosthesis ${ }^{10}$.

Taking into account that most of the brachial plexus injury patients are young, otherwise healthy patients, who have many years of productive life ahead, so an arm prosthesis could be an important aid for those patients selected for amputation ${ }^{17}$. However, some of these patients will use a prosthesis and some will not. Manual workers and patients who have difficulty converting hand dominance will be more likely to use a prosthesis ${ }^{5}$. The percentage of long-term wearers of prostheses, usually not exceeding $50 \%$ of the time, varies substantially ${ }^{18,19,20,21,22}$. The prosthesis is a useful tool to assist the intact limb ${ }^{23}$, but its active use may be limited by the usual lack of scapulothoracic control in pan plexus injuries. In those patients, the unstabilized shoulder is unable to support the weight of a prosthesis and cannot use it functionally ${ }^{11}$. In addition, many patients complain about insufficient prosthetic training, which certainly compromises its regular use $\mathrm{e}^{24}$.

The controversy about the indication for amputation in traumatic traction injuries of the brachial plexus still continues and, owing to the development of microsurgical techniques and consequent improvement in the outcome of these patients, recent studies have stated that amputation should no longer be considered an option in cases of global root avulsion ${ }^{25,26}$.

When faced with the decision to amputate the completely paralyzed upper limb or not, the pivotal issue is whether the patient will become a successful prosthetic user. This decision may be influenced by many factors such as the patient's sex, age, limb dominance, associated injuries, motivation and the support and experience of the medical care team. It is believed that arthrodesis helps stabilize the residual limb for simple daily activities and results in a more reliable prosthetic use'. However, the indications of arthrodesis of the shoulder are also matter for discussion. Although indicated by many authors ${ }^{2,3,9}$, some argue that arthrodesis of the shoulder, combined with amputation, should not be done, as this combination does not seem to enhance either the patient's ability to return to work or his ability to use his prothesis ${ }^{6}$. Moreover, the prolonged immobilization required to achieve arthrodesis may significantly interfere with the patient's rehabilitation ${ }^{5}$.

Usually, if the patient is athletically inclined and highly motivated, or if the flail limb (dominant or not) interferes with the patient's return to work or the accomplishment of daily 

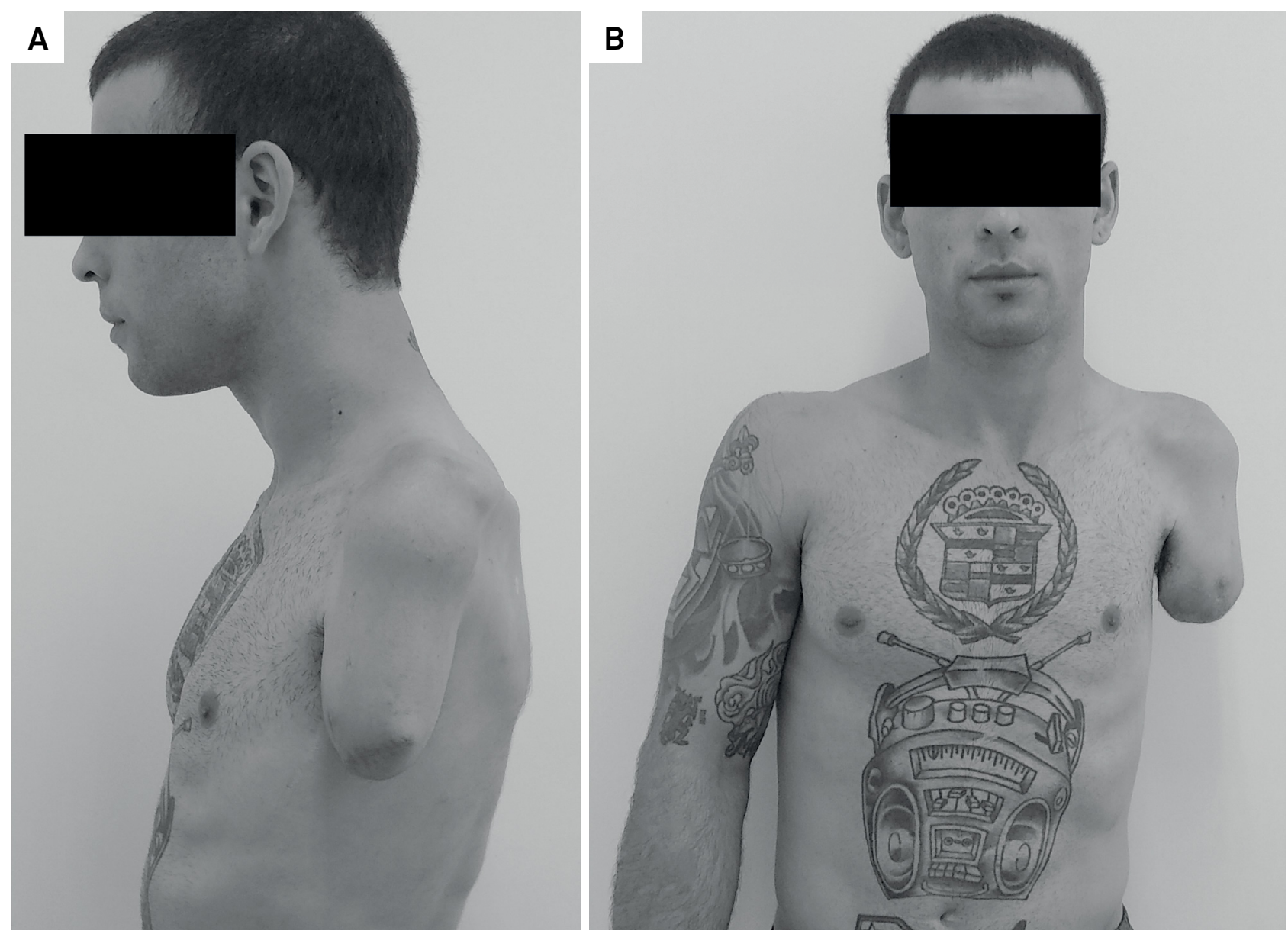

Figure. Patient after mid-arm amputation. A, lateral view; B, frontal view.

life tasks, or if it is a source of frequent infections, amputation seems to be a reasonable option ${ }^{8,10}$. The indications for elective amputation of the upper limb in traumatic brachial plexus injuries could be summarized in the following way': 1) flail upper extremity; 2) no prognosis for additional recovery; 3) failure of all possible surgical treatments; 4) patient dissatisfaction with lack of useful function and/or discomfort of the flail limb; 5) willingness to attempt prosthetic use, and 6) pain or discomfort secondary to inferior glenohumeral subluxation. Among the contraindications that should be mentioned is the paralysis of the muscles responsible for the stabilization of the scapula and for compensatory scapulothoracic motion following glenohumeral arthrodesis - the trapezius, levator scapulae, latissimus dorsi, serratus anterior, and rhomboid muscles ${ }^{27}$. Another obvious contraindication is the presence of active infection in the proximal humerus or glenohumeral joint. When considering amputation and arthrodesis, one should keep in mind that complications in the glenohumeral arthrodesis are possible, such as wound infection, bone nonunion and malpositioning of the arthrodesis. The above-elbow amputation could complicate matters as well. There is a relatively high incidence of phantom limb pain ${ }^{6}$ and, even with a good technique to protect and bury proximal nerve endings beneath the soft tissues, painful neuromas may develop and limit prosthetic use ${ }^{9}$.
Pain is an important issue in patients with traumatic brachial plexus injuries, as the majority of patients have pain as their chief complaint. It is important to differentiate between centrally-mediated neuropathic pain and mechanical pain. If the patient has post-traumatic deafferentation pain, he or she should be advised that the origin of this type of pain is central and is not affected by any peripheral maneuver ${ }^{3,5,28,29}$. On the other hand, the mechanical pain, probably related to traction of the paralyzed member on the glenohumeral joint and on the suspensory muscles of the scapula, is frequently improved by the amputation of the upper limb $b^{9,10}$.

\section{FINAL REMARKS}

Amputation should be specially considered when the patient requests it, usually after failure of recovery after initial nerve reconstruction ${ }^{30}$. However, if the patient is clearly not willing to use a prosthesis and elects to retain the limb for cosmetic reasons, no surgery should be indicated.

When performed for the right reason, elective amputation should not be seen as a failure of treatment, but rather as a positive step towards rehabilitation ${ }^{8}$. 
1. Hendry AM. The treatment of residual paralysis after brachial plexus injuries. J Bone Joint Surg Br. 1949;31B:42-9.

2. Seddon HJ. Surgical disorders of the peripheral nerves. Edinburgh: Churchill Livingstone; 1972.

3. Parry CB. The management of injuries to the brachial plexus. Proc Roy Soc Med. 1974;67(6 Pt 1):488-90.

4. Yeoman PM, Seddon HJ. Brachial plexus injuries: treatment of the flail arm. J Bone Joint Surg. 1961;43B(3):493-500.

5. Ransford AO, Hughes SPF. Complete brachial plexus lesions. a ten year follow-up of twenty cases.J Bone Joint Surg. 1977;59B(4):417-20.

6. Rorabeck $\mathrm{CH}$. The management of the flail upper extremity in brachial plexus injuries. J Trauma. 1980;20(6):491-3. https://doi.org/10.1097/00005373-198006000-00010

7. Wynn Parry CB, Frampton V, Monteith A. Rehabilitation of patients following traction lesions of the brachial plexus. In: Terzis JK, editor. Microeconstruction of nerve injuries. Philadelphia: WB Saunders; 1987. p. 483-96.

8. Wilkinson MCP, Birch R, Bonney G. Brachial plexus injury: when to amputate? Injury.1993;24(9):603-5. https://doi.org/10.1016/0020-1383(93)90123-N

9. Bedi A, Miller B, Jebson PJL. Combined glenohumeral arthrodesis and above-elbow amputation for the flail limb following a complete posttraumatic brachial plexus injury. Tech Hand Up Extrem Surg. 2005;9(2):113-9. https://doi.org/10.1097/01.bth.0000168165.61469.39

10. Birch R. Surgical disorders of the peripheral nerves. 2nd ed. London: Springer; 2011

11. Maldonado AA, Kircher MF, Spinner RJ, Bishop AT, Shin AY. The role of elective amputation in patients with traumatic brachial plexus injury.J Plast Reconstr Aesthet Surg. 2016;69(3)311-7. https://doi.org/10.1016/j.bjps.2015.10.019

12. Narakas A. Surgical treatment of traction injuries of the brachial plexus. Clin Orthop Relat Res. 1978;(133):71-90.

13. Sedel $L$. The results of surgical repair of brachial plexus injuries. J Bone Joint Surg Br. 1982;64(1):54-66.

14. Allieu Y, Cenac P. Is surgical intervention justifiable for total paralysis secondary to multiple avulsion injuries of the brachial plexus? Hand Clin. 1988;4(4):609-18.

15. Harvey ZT, Potter BK, Vandersea J, Wolf E. Prosthetic advances. J Surg Orthop Adv. 2012;21(1):58-64.

16. Smith JK, Myers KP, Holloway RG, Landau ME. Ethical considerations in elective amputation after traumatic peripheral nerve injuries. Neurol Clin Pract. 2014;4(4): 280-6. https://doi.org/10.1212/CPJ.00000000000000049

17. Durance JP, O'Shea B. Upper limb amputees:

a clinic profile. Int Disabil Stud. 1988;10(2):68-72.

https://doi.org/10.3109/09638288809164107
18. Datta D, Selvarajah K, Davey N. Functional outcome of patients with proximal upper limb deficiency: acquired and congenital. Clin Rehabil. 2004;18(2):172-7. https://doi.org/10.1191/0269215504cr716oa

19. Jones LE, Davidson JH. The long-term outcome of upper limb amputees treated at a rehabilitation centre in Sydney, Australia. Disabil Rehabil. 1995;17(8):437-42. https://doi.org/10.3109/09638289509166658

20. Herberts P, Körner L, Caine K, Wensby L. Rehabilitation of unilateral below-elbow amputees with myoelectric prostheses. Scand $J$ Rehabil Med. 1980;12(3):123-8.

21. McFarland LV, Winkler SLH, Heinemann AW, Jones M, Esquenazi A. Unilateral upper-limb loss: satisfaction and prosthetic-device use in veterans and servicemembers from Vietnam and OIF/OEF conflicts. J Rehabil Res Dev. 2010;47(4):299-316. https://doi.org/10.1682/JRRD.2009.03.0027

22. Pinzur MS, Angelats J, Light TR, Izuierdo R, Pluth T. Functional outcome following traumatic upper limb amputation and prosthetic limb fitting. J Hand Surg Am. 1994;19(5):836-9. https://doi.org/10.1016/0363-5023(94)90197-X

23. Bhaskaranand K, Bhat AK, Acharya KN. Prosthetic rehabilitation in traumatic upper limb amputees (an Indian perspective). Arch Orthop Trauma Surg. 2003;123(7):363-6. https://doi.org/10.1007/s00402-003-0546-4

24. Østlie K, Lesjø IM, Franklin RJ, Garfelt B, Skjeldal OH, Magnus P. Prosthesis use in adult acquired major upper-limb amputees: patterns of wear, prosthetic skills and the actual use of prostheses in activities of daily life. Disabil Rehabil Assist Technol. 2012;7(6):479-93. https://doi.org/10.3109/17483107.2011.653296

25. Terzis JK, Kostopoulos VK. The surgical treatment of brachial plexus injuries in adults. Plast Reconstr Surg. 2007;119(4):73-92. https://doi.org/10.1097/01.prs.0000254859.51903.97

26. Terzis JK, Vekris MD, Soucacos PN. Brachial plexus root avulsions. World J Surg. 2001;25(8):1049-61. https://doi.org/10.1007/s00268-001-0058-8

27. Clare DJ, Wirth MA, Groh GI, Rockwood CA. Shoulder arthrodesis. J Bone Joint Surg Am. 2001;83-A(4):593-600. https://doi.org/10.2106/00004623-200104000-00018

28. Fletcher I. Traction lesions of the brachial plexus. Hand;1969;1 (2):129-36. https://doi.org/10.1016/0072-968X(69)90081-3

29. Narakas A. Symposium on brachial plexus function and surgery. Periph Nerve Repair Regen. 1986;1:59-68.

30. Hems T. Brachial plexus injuries. In: Tubbs RS, Rizk E, Shoja MM, Loukas M, Barbaro N, Spinner RJ , editors. Nerve and nerve injuries. Vol 2: Pain, treatment, injury, disease, and future directions. San Diego: Academic Press; 2015. p. 681-706. 